INTERNATIONAL JOURNAL OF RESEARCHES IN BIOSCIENCES, AGRICULTURE \& TECHNOLOGY (C) VISHWASHANTI MULTIPURPOSE SOCIETY (Global Peace Multipurpose Society) R. No. MH-659/13(N) www.vmsindia.org

\title{
EFFECT OF STORAGE CONTAINERS ON MYCOFLORA AND GERMINABILITY OF SOYBEAN DURING STORAGE
}

\section{${ }^{1}$ Lambat A., ${ }^{1}$ Babhulkar V., ${ }^{1}$ Gadewar R., ${ }^{2}$ Charjan S., ${ }^{3}$ Lambat P., ${ }^{4}$ Parate R. and ${ }^{4}$ Thul $A$.}

\author{
${ }^{1}$ Sevadal Mahila Mahavidyalaya Nagpur (M.S) India \\ ${ }^{2}$ College of Agriculture (Dr. PDKV's) Nagpur (M.S) India \\ ${ }^{3}$ Shri Mathuradas Mohata Science College, Nagpur (M.S) India \\ ${ }^{4}$ Anand Niketan College of Agriculture Warora (M.S) India \\ Email: rajeshgadewar29@gmail.com
}

\begin{abstract}
Soybean (Glycine Max. L. ) is a valuable crop for its high protein and oil content and is used in our daily diet. The soybean seeds stored for 6,12 and 18 months in three types of containers viz. jute, cloth and polyethylene bags. Storage of soybean seeds in polyethylene bag showed greater germinability and lesser seed invasion by the fungal flora than jute and cloth bags during storage.
\end{abstract}

Keywords: Soybean, Container, Germination, Mycoflora

\section{Introduction:}

Soybean [Glycine Max (L). Merr.] is infected with a large number of field and storage fungi that are responsible for seed-rot [Fusarium equiseti (Corda) Sacc.] seedling blight (Phomopsis sojae Lehman), root - and - shoot rot (Phytophthora megasperma Drechsl. Var sojae Hildebrand), foliar infection as well as pod-blight disease [ Diaporthe phaseorum (Cke. \& Fll.) Sacc. Var sojae (Leham Wehm) ] (Sharma 1990, Singh, 1991).

The atmospheric condition plays an important role in the survival or elimination of organisms. Variation in the climatic conditions occur after transfer of seeds from field conditions to the storage containers. Since information on the incidence of mycoflora and germinability during storage is meagre in soybean, an experiment was conducted on this aspect.

\section{Materials and methods:}

Soybean "MACS 13" seeds were used in the various phases of this study, produced in 2016 (rainy season). The seeds were cleaned, dried with moisture content equilibrated to $9 \%$ and packed in 3 types of containers, viz. jute, cloth (pervious to moisture) and polyethylene bag, 700 gauge (moisture-proof) of size $20 \mathrm{~cm} \mathrm{x} 30 \mathrm{~cm}$ respectively.

The containers were sealed and stored in wire-mesh almirah in masonry building having cement walls, roof and floor, under ambient temperature $\left(10.6-43.4^{\circ} \mathrm{C}\right)$ and relative humidity $(35.8-87.3 \%)$ for 18 months. Then $100 \mathrm{~g}$ seeds were taken in a round plastic container. Sufficient quantity $(40 \%)$ of gum solution was added, to form a thin layer over the seeds. A required quantity of fungicides $(0.3 \mathrm{~g} / 100 \mathrm{~g})$ was then added and the container was closed and shaken vigorously till formation of a uniform coating of fungicides over the seeds. The observations on germination and fungal flora was recorded at 6-month intervals. The germination percentage was recorded (ISTA, Zurich 1985) From 400 seeds of soybean, the fungi isolated following standard blotter and agar-plate methods (ISTA, Zurich 1976) were noted.

\section{Results and discussion:}

The maximum percentage of incidence of fungi was observe din jute and cloth bags. Polyethylene bags provided much protection to soybean seeds in preventing the development of fungal colonies both quantitative and species-wise. This finding confirms the result of Dwivedi and Shukla (1990) and Lambat et al (2011).

The incidence of various fungi recorded at different periods of storage is given in Table 1.With the advancement in the storage period, the incidence of storage fungi increased rapidly. Christensen (1973) and Srivastava and Gupta (1980) also reported increase in the percentage of storage fungi and loss in the field fungi under storage. This fluctuation (occurrence or non-occurrence of a number of fungi, at different intervals) may be attributed mainly 
to the fluctuation in the atmospheric relative humidity and temperature during the period of storage, which influenced the growth and development of fungi. Requirement of relative humidity and temperature vary for the growth and development of different fungi. This might have resulted in the appearance of a particular fungus at one instant and nonappearance at the other. The increase in the number of infected seeds was due to increase in mycoflora. It is better to store in polyethylene bag to preserve greater seed germinability and lesser seed invasion by the fungal flora during storage. The seeds treated with fungicides were better than the untreated ones. Thiram $(0.3 \%)$ proved superior, showing maximum germination percentage, followed by captan, carbendazim and captafol (Table-1)

Table-1: Effect Of Storage Containers On Mycoflora And Germinability Of Soybean During storage

\begin{tabular}{|c|c|c|c|c|c|c|c|c|c|c|}
\hline \multirow[t]{3}{*}{ Treatment } & \multicolumn{9}{|c|}{ Fungus-infested(\%) seeds of soybean at } & \multirow{3}{*}{$\begin{array}{c}\text { Initia } \\
1\end{array}$} \\
\hline & \multicolumn{3}{|c|}{6 months } & \multicolumn{3}{|c|}{12 months } & \multicolumn{3}{|c|}{18 months } & \\
\hline & JB & CB & PB & JB & CB & PB & JB & CB & PB & \\
\hline $\begin{array}{l}\text { Alternaria alternate (Fr. ) } \\
\text { Keissler }\end{array}$ & 6.26 & 6.50 & 6.25 & --- & --- & 2.25 & 0.75 & --- & 0.25 & 7.25 \\
\hline Ascochyta sojicola Abram & 1.25 & 0.75 & --- & --- & --- & --- & --- & --- & --- & 2.25 \\
\hline Aspergillus flavus L. Ex-Fr. & 4.75 & 3.75 & 1.75 & 17.25 & 15.50 & 7.75 & 37.00 & 36.25 & 25.50 & 1.75 \\
\hline A. melleus Yukawa & --- & --- & --- & 4.50 & 5.00 & 0.75 & 7.75 & 8.00 & 6.25 & --- \\
\hline A. niger Van Tiegh. & 2.75 & --- & 3.25 & 0.75 & 9.25 & 8.75 & 6.75 & 32.00 & 25.00 & 0.75 \\
\hline A. Parasiticus Speare & 3.25 & 2.25 & 0.50 & 5.25 & 6.00 & 3.75 & 10.25 & 9.50 & 6.00 & --- \\
\hline $\begin{array}{l}\text { Cercospora kikuchii (Mats } \\
\& \text { Tommy) W.M. Gardner }\end{array}$ & 2.75 & 2.75 & 0.75 & 0.50 & --- & $\begin{array}{ll}-- \\
-1\end{array}$ & $\begin{array}{ll}-- \\
\end{array}$ & $\begin{array}{ll}-- \\
\end{array}$ & --- & 0.50 \\
\hline $\begin{array}{l}\text { Chaetomium spinosum } \\
\text { Chivers. }\end{array}$ & 2.25 & 1.25 & --- & 2.75 & 2.50 & 0.75 & 4.25 & 4.00 & 4.00 & 0.75 \\
\hline $\begin{array}{l}\text { Curvularia Lunata } \\
\text { (Wakker) Boedn. }\end{array}$ & 3.25 & 2.00 & 1.75 & --- & --- & --- & --- & --- & --- & 0.75 \\
\hline $\begin{array}{l}\text { Fusarium equiseti (Corda) } \\
\text { Sacc. }\end{array}$ & 4.75 & 3.25 & 1.75 & 4.00 & 4.25 & 1.25 & 3.25 & 2.50 & 1.75 & $\begin{array}{c}-- \\
\end{array}$ \\
\hline F.manliforme Sheldon & 2.25 & 3.00 & 0.75 & 3.75 & 4.50 & 2.50 & 3.25 & 3.00 & 3.00 & --- \\
\hline $\begin{array}{l}\text { Macrophomina Phaseloina } \\
\text { (Tassi) Goid. }\end{array}$ & 3.75 & 3.00 & 2.50 & 1.75 & 1.75 & $\begin{array}{ll}--- \\
\end{array}$ & $\begin{array}{ll}-- \\
\end{array}$ & $\begin{array}{ll}-- \\
-1\end{array}$ & --- & 1.50 \\
\hline $\begin{array}{ll}\text { Penicillium } & \text { oxalicum } \\
\text { Currie \& Thom. } & \end{array}$ & 1.75 & 2.25 & & 3.75 & 4.25 & 2.25 & 8.25 & 9.50 & 7.25 & --- \\
\hline Rhizoctonia Solani Kuhn. & 2.25 & 2.50 & 2.00 & 0.75 & 0.25 & --- & $\begin{array}{ll}-- \\
--\end{array}$ & --- & --- & 0.75 \\
\hline Rhizopus nigricans Ehr. & 4.75 & 3.25 & 1.25 & 8.25 & 8.00 & 7.25 & 20.25 & 26.00 & 12.00 & --- \\
\hline Total organisms & 14 & 14 & 11 & 12 & 11 & 10 & 10 & 9 & 10 & 9 \\
\hline Total incidence (\%) & 46.00 & 39.75 & 20.00 & 61.75 & 60.75 & 35.25 & $\begin{array}{l}128.0 \\
0\end{array}$ & $\begin{array}{l}133.7 \\
5\end{array}$ & 91.00 & 16.25 \\
\hline Germination (\%) & --- & $\begin{array}{ll}-- \\
\end{array}$ & --- & --- & --- & --- & --- & --- & --- & --- \\
\hline Control (untreated) & 92 & 91 & 92 & 79 & 77 & 86 & 30 & 39 & 56 & 90 \\
\hline Carbendazim $(0.3 \%)$ & 97 & 96 & 100 & 87 & 87 & 90 & 40 & 48 & 65 & 99 \\
\hline Captan $(0.3 \%)$ & 97 & 96 & 98 & 90 & 90 & 92 & 45 & 52 & 69 & 99 \\
\hline Captafol $(0.3 \%)$ & 96 & 97 & 97 & 85 & 86 & 91 & 34 & 44 & 62 & 99 \\
\hline Thiram $(0.3 \%)$ & 98 & 98 & 99 & 92 & 94 & 95 & 45 & 56 & 71 & 100 \\
\hline
\end{tabular}

J.B.: Jute Bag, CB: Cloth Bag, P.B.: Polyethylene bag 


\section{References:}

ISTA, Zurich, 1976, International rules for seed testing. Seed Science and technology 4 : 108

ISTA, Zurich. 1985, International rules for seed testing. Seed Science and Technology 13: 299-513.

Christensen C.M. 1973. Loss of viability in storage microflora. Seed Science and Technology 1: 547-62.

Dwivedi S.N. and Shukla T.N. 1990. Effect of methods of storage on germinability and mycoflora of gram (Cicer arietinum L. ) seed. Seed Research 18 (1) : 82-5.

A.Lambat, R. Gadewar,P. Charde, S. Charjan, K. Cherian and P. Lambat.2011. Effect of Post harvest operations on seed quality of urdbean. Proceeding of International Conference in Agriculture Engineering held at Chonburi, Thailand on 31 March-1 April.2011.

Sharma A.K. 1990. Effect of metabolites of some seed-borne fungi of seed mycoflora and germination of soybean (Glycine max (L.) Merr.) Proceedings of International Conference on Seed Science and Technology, held during 21-25 February 1990, at New Delhi, Abstract No. L-8.

Singh D.P. 1991. Seed-borne diseases of soybean and their control. Seeds and Farms $1(3,4): 12-4$.

Srivastava R.N. and Gupta J.S. 1980. Effect of storage on the mycoflora and viability of pansy and verbena seeds. Seeds and Farms 6 (4): 25-8. 